DOI: $\underline{10.35619 / \text { iiu.v1i10.153 }}$

Побірченко Наталія

доктор педагогічних наук, професор, професор надзвичайний на факультеті суспільних та гуманітарних наук Державного вищого навчального закладу імені Вітелона в Легніці, Легніца, Польща ORCID: 0000-0003-2125-7713 e-mail: pobirchenko_n@mail.ru

\title{
МЕТОДИЧНІ АСПЕКТИ КОНЦЕПЦІЇ ГУМАНІСТИЧНОГО ВИХОВАННЯ В. О. СУХОМЛИНСЬКОГО
}

\begin{abstract}
Анотація. У статті розкрито ключові методичні аспекти концепції гуманістичного виховання В.О.Сухомлинського, головною метою якої $є$ дитина, формування іiі внутрішнього світу, прищеплення високих духовних потреб, забезпечення всебічного розвитку. Автор розглядає систему поглядів великого педагога-гуманіста на виховання дитини, які можуть бути використані сучасними вчителями у практичній діяльності. Серед ключових методичних аспектів концепції визначено, насамперед, бачення дитини як найдорожчого скарбу у світі, який потребує любові, поваги, віри, доброзичливості, тепла і розумної вимогливості (принцип дитиноцентризму); єдність сім'ї і школи у виховному процесі; уміння вчителя спілкуватися з учнями, знаходити духовні точки дотику у взаєминах з дітьми, аби мати на них позитивний вплив; значення ролі керівника школи у створенні в колективі високої духовності, родинної теплоти і творчої атмосфери.
\end{abstract}

Ключові слова. В. О. Сухомлинський, гуманістичне виховання, концепція гуманістичного виховання, методичні аспекти.

Постановка проблеми. Швидкі технологічні зміни, бурхливий технічний прогрес, культурні та економічні виклики породжують величезний розрив між досягненнями в галузі науково-технічного прогресу і станом духовного розвитку людини: «зростає значущість особистої вигоди, зневаження гідності людини, девальвація цінності моральних взаємин, применшення соціальної відповідальності» (Поніманська, 2013).

Тому постає проблема гуманізації суспільного життя, що потребує переорієнтації на відродження гуманістичних підходів до виховання дітей і молоді. Одним із таких шляхів є звернення до надбань національної педагогічної науки і практики, в основі яких лежить орієнтація на розвиток особистості, відродження гуманістичних традицій у виховній системі.

Саме такою невичерпною скарбницею $\epsilon$ педагогічна спадщина Василя Олександровича Сухомлинського, який залишив нам безцінну концепцію гуманістичного виховання, центром якої є особистість дитини.

Аналіз останніх досліджень 3 проблеми. Дослідження педагогічної спадщини В. Сухомлинського в останні роки здійснюють А. Богуш, Л. Бондар, Н. Калініченко, О. Петренко, О. Савченко, О. Сухомлинська, В. Федяєва та ін. (Савченко, 2003; Сухомлинська, 2013). Проблема гуманізації освіти є предметом наукових розвідок C. Барабаш, I. Беха, В. Кременя, О. Пометун, Т Поніманської, В. Риндак та ін. (Барабаш, 2001; Бех, 2006; Поніманська, 2013). Педагогіку гуманізму В. Сухомлинського вивчали І. Буєва, М. Мухін, Н. Козак, А. Кокеріл, Н. Скрипник, I. Сухоярська та ін. (Буева, 2006; Кокерилл, 2013; Сухоярська, 2008).

Мета статті: схарактеризувати методичні аспекти концепції гуманістичного виховання В. О. Сухомлинського.

Виклад основного матеріалу дослідження. Василь Олександрович Сухомлинський створював концепцію гуманістичного виховання у 50-60-ті роки 
минулого століття, в час «хрущовської відлиги», коли в суспільстві з'явилися надії на демократичні перетворення. Однак, відлига закінчилась і великого учителя обірвали на півслові.

Гуманізм, обраний талановитим учителем головним принципом власної концепції виховання, відомий у педагогіці багатьох цивілізацій. Але у підпорядкованій ідеології диктатури радянській школі вперше прозвучав на повний голос у маленькому тихому Павлиші. Звичайно, далеко не все із задуманого Василь Олександрович встиг випробувати і здійснити. Короткий вік судився, а головне - надто самостійний, вдумливий і творчий академік з Павлиша відходив від ідеологічних догм у вихованні, створивши власну гуманістичну концепцію. I цим став незручний для керівної верхівки.

Наріжний камінь педагогічної концепції дитиноцентричний принцип. У центрі виховного процесу - дитина, іiї розвиток, формування внутрішнього світу. Педагог-новатор у радянській, що називається наскрізь заідеологізованій школі, запровадив власну, авторську систему виховання, на яку досі орієнтується учительство в різних кінцях світу. I грунтувалась вона на вічних цінностях - добра, справедливості, поваги до батьків, любові до рідного краю, рідної мови. 3 позицій сьогодення очевидно, що це була спроба, до того ж успішна, врятувати дітей від згубного впливу «подвійної моралі», притаманної тому часу на теренах радянської імперії. Тільки змалку прищеплені дитині принципи порядності, справедливості, уміння цінувати честь пробуджують в людині людину, додають особистості гарту і сил жити по-справжньому, за будь-яких умов не зраджувати своїх переконань.

Торкнемося деяких, найважливіших, на наш погляд, положень концепції В. О. Сухомлинського.

НАВЧАТИ ЧИ ВИХОВУВАТИ? Це запитання завжди мало риторичний, навіть, так би мовити, гамлетівський характер. Свого часу побутувало переконання, що справа вчителя - нести знання. Вихователь - то інша професійна категорія. Можна знайти немало прикладів того, що вітчизняна школа і до сьогодні орієнтована на об'єм знань, які треба дати учню, в кінцевому результаті - на підготовку до закладу вищої освіти. Позиція видатного педагога у співвідношеннях формули «навчання - виховання» чітка і визначена. На думку В. О. Сухомлинського, «...навчання - це лише одна $з$ пелюсток тієї квітки, що називається вихованням у широкому розумінні цього поняття. У вихованні немає головного і другорядного, як немає головної пелюстки серед багатьох, що створюють красу квітки. У вихованні все головне - і урок, і розвиток різнобічних інтересів дітей поза уроком, i взаємовідносини вихованців у колективі» (Сухомлинський, 1977 a, с. 54).

ПРАЦЯ як могутній фактор виховання посідає одне 3 чільних місць у гуманістичній педагогічній концепції $\mathrm{B}$. О. Сухомлинського. Принцип єдності трудового виховання i загального розвитку - морального, інтелектуального, естетичного, фізичного; розвиток індивідуальності у праці; суспільно корисна спрямованість; раннє залучення до продуктивної праці, ії різноманітність, наявність конкретного результату. Вихованці Василя Олександровича закладали перші полезахисні лісосмуги на Кіровоградщині, рятуючи земельні масиви від ерозії. У Павлиші при школі був власний плодовий розсадник: це нелегка повсякденна робота протягом всього року. Проте - потребує певної кваліфікації і творчості: комбінації зі щепленням різних сортів, досліди 3 використанням різних видів удобрення. У загальноосвітніх школах того часу почала з'являтися перша техніка - станки у майстернях, електродвигуни. В. О. Сухомлинський був прихильником конструювання спеціальної техніки «дитячих масштабів», яку можна було б використовувати для реальної продуктивної роботи.

ШКОЛА І СІМ'Я. Основа гуманістичної концепції В. О. Сухомлинського - єдність сім'і і школи у виховному процесі. Більше того, вплив родини на всі сфери 
формування і зростання юної особистості - вирішальний. Перші уявлення про добро і зло, честь і сором, правду і кривду дитина отримує з сімейного кола. Віддзеркалюється на долі дітей і приклад сімейного життя батьків, а на рівні підсвідомості, будучи дорослими, нащадки приймають його за еталон для наслідування. Хороша дружна сім'я - найкраща школа для виховання доброти, щирості, чуйності. Навчити цьому дітей академічними настановами просто неможливо, поняття засвоюються в процесі спілкування 3 дорослим, гри, сприйняття казки. Але чи всі дорослі, чи кожна сім'я в змозі по-справжньому виконати свою виховну роль у становленні особистості? На жаль, далеко не кожна. На заваді - дефіцит освіти, педагогічних знань, культури, часу, різного роду драматичні колізії (неповні сім’ї, хвороби, пияцтво, асоціальна поведінка батьків). Ліквідовувати ці прогалини допомагала створена В. О. Сухомлинським у Павлиші батьківська школа. Цю форму просвітницької роботи серед батьків можна назвати провісником сучасних клубів психологічної допомоги. Батьків тут вчили вибудовувати гармонійні стосунки 3 дітьми, навчали розумної вимогливості у вихованні. Для дітей мудрий педагог придумав школу Сердечності: у формі гри школярі тут займалися виготовленням подарунків-сюрпризів для батьків. У програмі цієї школи було свято Троянди, свято Квітів, свято Врожаю, а найулюбленіше - свято Матері. В школі В. О. Сухомлинського панував культ матері - це також одна із складових його концепції гуманізації.

УЧИТЕЛЬ І УЧНІ. Василь Олександрович Сухомлинський називав учительську професію людинознавством, суть якого - постійне проникнення в складний духовний світ дитини. «Прекрасна риса - повсякчас відкривати в людині нове, дивуватися новому, бачити людину в процесі ії становлення - один 3 тих коренів, які живлять покликання до педагогічної праці» (Сухомлинський, 1976, с. 422.). Давно відоме таке явище: якщо в школі працює, приміром, талановитий учитель математики, в кожному класі з'являються талановиті, захоплені математикою учні. Для когось ця обставина стане вирішальною при виборі професії. Таким чином, особистість учителя значною мірою позначається на долі його вихованців.

У педагогічній концепції В. О. Сухомлинського наскрізною ідеєю є теза про те, що характер взаємин між учителем і учнями - вирішальний фактор у шкільному вихованні. Основи гуманістичних стосунків між вчителем і вихованцями були закладені в Павлиші, у Школі радості Василя Олександровича Сухомлинського. Гуманістична концепція може прижитися тільки у школі з сильним, непересічним педагогічним колективом. Як зазначав В. О. Сухомлинський, справжній колектив там, де $\epsilon$ творче ядро педагогів, одухотворених великою гуманною ідеєю, в руках яких найбільша 3 усіх цінностей світу - людина. А тому «від нас, від нашого вміння, майстерності, мистецтва, мудрості залежать ії життя, здоров'я, розум, характер, воля, громадянське й інтелектуальне обличчя, іiі місце i роль у житті, іiі щастя» (Сухомлинський, 1977 b, с.420).

У книзі «Сто порад учителеві» В. О. Сухомлинський подав конкретні безцінні методичні поради вчителеві, які можна назвати хрестоматією з методики виховання і навчання учня, настільною книгою як для починаючого вчителя, так і для вчителя 3 багаторічним стажем роботи. Зазначимо лише окремі з них: знати дитину (без знання душі - виховання сліпе); любити кожну дитину, якою вона $є$ («кожний, хто вирішує присвятити своє життя вихованню дитини, має бути терплячим до дитячих слабостей» (Сухомлинський, 1976, с.423); поважати дитину, іiї гідність, особистість, бо кожна дитина - неповторна; вірити в дитину («невіру в людину ... назвав би раковою пухлиною недоброзичливості» (Сухомлинський, 1976, с.431); бути доброзичливим до дитини («Доброзичливість педагога означає, насамперед, уміння не допустити, щоб дитина стала поганою, застерегти ії від помилкових кроків»; «Душа дитини має бути підготовлена до виховання ласкою, добротою, сердечністю» (Сухомлинський, 1976, c.423, с.435); забезпечувати індивідуальний підхід кожній дитині (Пам'ятайте, що нема й бути не може абстрактного учня» (Сухомлинський, 1976, с.436); дбайливо ставитись 
до природи і духовного світу дитини, бо кожна дитина це - неповторний світ; виховувати людське благородство у кожної дитини («Виховання людського благородства в дитячому серці починається 3 олюднення його ставлення до людей, одухотворення цього ставлення чистими, піднесеними почуттями поваги до людини» (Сухомлинський, 1976, с.546); домагатися створення ненавмисності педагогічного впливу («Однією 3 умов ефективності педагогічного впливу $\epsilon$ обстановка ненавмисності цього впливу. Іншими словами, учневі не треба в кожну дану мить знати, що вчитель його виховує» (Сухомлинський, 1976, с.654).

ДИРЕКТОР. «Справжнє керівництво школою починається ... там, де нескінченний потік явищ постає перед директором як взаємозв'язок проблем» - такий висновок народився з бесід і суперечок учасників школи педагогічної культури у Павлиші. Як зазначав В.О. Сухомлинський, колеги дискутували на різні теми: як правильно збалансувати адміністративно-господарські обов'язки 3 педагогічною роботою, щоб директор нарощував вчительську майстерність; від яких чинників більше залежить якість уроку, інтелектуальний рівень шкільного середовища і родини; як виховувати бажання вчитися, адже ця проблема тисячами ниток пов'язана $з$ усім навчальновиховним процесом. На одному твердженні сходилися всі: аби стати хорошим директором, треба передусім бути хорошим учителем. «Учителем учителів, - а тільки вчитель учителів і $є$ справжнім керівником, якому вірять і якого поважають, - можна стати лише тоді, коли з кожним днем усе більше заглиблюєшся в деталі, в тонкощі педагогічного процесу, коли перед тобою відкриваються все нові й нові грані того, що можна назвати мистецтвом впливу на душу людини», - зазначав Василь Олександрович на сторінках книги «Розмова 3 молодим директором» (Сухомлинський, 1977 b, c. 398). Основоположною істиною В. О. Сухомлинський вважав твердження про те, що особистість педагога творить особистість учня. I вимагав від учителів: «Добивайтеся того, щоб дитина була в центрі уваги педагогічного колективу, в центрі вашої уваги» (Сухомлинський, 1977 а, с. 442). Тому, що «...духовно багата, морально яскрава, інтелектуально самобутня особистість здатна і у вихованцях своїх поважати і виховувати особистість; а безликість знеособлює і вихованців, сіє навколо себе убозтво» (Сухомлинський, 1977 а, с. 477).

ПЕРЕДБАЧЕННЯ. Дослідники творчості В. О. Сухомлинського часто підкреслюють, що видатний педагог випередив свій час, створивши школу XXI століття. Можна погоджуватись чи заперечувати ключові положення педагогічної концепції В. О. Сухомлинського, але більшість з них витримали актуальність і до сьогоднішнього дня, а окремі з них носять характер передбачення. Тож, зупинимося на одному з аспектів його педагогічної концепції, який сьогодні доволі рідко потрапляє в поле зору дослідників. Йдеться про моральне виховання, прищеплення порядності у стосунках молоді, цнотливість, бережне ставлення до жінки. Про систему моральних табу, яку сьогодні, що називається, відправили на смітник історії. Хоча Василь Олександрович працював 3 дітьми докомп'ютерної, почасти навіть дотелевізійної епохи, цій темі він приділяв дуже багато уваги. Можливо, це прогноз геніального педагога, який передбачав загрозу, що насувалась на суспільство в близькому майбутньому. Сумний прогноз виявився реальним: розмиваються межі між добром і злом, правдою i кривдою, честю i безчестям. Хвиля бруду яка безперервно вихлюпується з телеекранів, викривляє у дітей уявлення про самих себе.

Висновки і перспективи подальших розвідок. Отже, розглянувши деякі методичні аспекти концепції гуманістичного виховання в спадщині Василя Олександровича Сухомлинського, ми ще раз переконалися в їхній актуальності, далекоглядності, невичерпності і геніальності. Завдання кожного вчителя, кожного педагога черпати 3 цієї криниці знань постійно і якомога більше. Концепцію гуманістичного виховання, розроблену В. О. Сухомлинським, можна вважати хрестоматією методики виховання і навчання учня, яка повинна стати настільною, що називається must-read, книгою як для починаючого вчителя, так і для вчителя 3 
багаторічним стажем роботи.

Перспективи подальших наукових розвідок вбачаємо у дослідженні методики виховання духовності особистості в гуманістичній педагогічній системі В. О. Сухомлинського та у розробці методичних рекомендацій із вдосконалення гуманістичного виховання учнів у нових соціокультурних умовах.

\section{СПИСОК ВИКОРИСТАНИХ ДЖЕРЕЛ}

Поніманська, Т. (2013). Вихователь і дитина у концепції гуманістичного виховання В. Сухомлинського. Наукові записки [Кіровоградського державного педагогічного університету імені Володимира Винниченка]. Сер.: Педагогічні науки. Вип. 123 (1). c. $249-253$.

Савченко, О. (2003). Гуманізм педагогіки Василя Сухомлинського. Ocвima України. 19 серп. (№ 62/63). с. 5.

Сухомлинська, О. (2013). Школа Сухомлинського у Павлиші - погляд крізь призму часу. Київ : Педагогічна думка. 123 с.

Барабаш, С. (2001). Філософія серця, або гуманізм Василя Сухомлинського. Дзеркало тижня. 6-12 жовт. (№ 39). с. 6. $273 \mathrm{c}$

Бех, I. (2006). Виховання особистості. Сходження до духовності. Київ : Либідь.

Буева, И. (2006). В. А. Сухомлинский: гуманистическая парадигма педагогического менеджмента : монография. Н. Новгород : ВГИПУ ; Оренбург : ГОУ ОГУ. 124 с.

Кокерил, А. (2013). Сухомлинський і XXI століття. Педагогіка і психологія. № 4. C.5-15.

Сухоярська I. (2008). Гуманізм як основа педагогічної системи Сухомлинського. Початкова освіта. № 23-24. с. 6-7.

Сухомлинський, В. (1977 а). Павлиська середня школа. Вибрані твори в 5 томах. Т. 4. Київ: Радянська школа. с.7-302.

Сухомлинський, В. (1976). Сто порад учителеві. Вибрані твори в 5 томах. Том 2. Київ: Радянська школа, 1976. с.419-657.

Сухомлинський, В. (1977 б). Розмова 3 молодим директором. Вибрані твори у 5 mомах. Т. 4. Київ: Радянська школа. с.303-629.

\section{REFERENCES}

Ponimanska, T. (2013). Vykhovatel i dytyna u kontseptsii humanistychnoho vykhovannia V. Sukhomlynskoho [Educator and Child in the Sukhomlynskyi Concept of Humanistic Education]. Naukovi zapysky [Kirovohradskoho derzhavnoho pedahohichnoho universytetu imeni Volodymyra Vynnychenka]. Ser.: Pedahohichni nauky. Vyp. 123 (1). s. 249-253. (in Ukrainian)

Savchenko, O. (2003). Humanizm pedahohiky Vasylia Sukhomlynskoho [Humanizm of Vasyl Sukhomlynskyi's Pedagogy]. Osvita Ukrainy. 19 serp. (No62/63. S. 5 (in Ukrainian)

Sukhomlynska, O. (2013). Shkola Sukhomlynskoho u Pavlyshi - pohliad kriz pryzmu chasu [Sukhomlynskyi School in Pavlysh - a View through the Prism of Time]. Kyiv : Pedahohichna dumka. 123 s. (in Ukrainian)

Barabash, S. (2001). Filosofiia sertsia, abo humanizm Vasylia Sukhomlynskoho [Philosophy of the Heart, or Humanism of Vasyl Sukhomlynskyi]. Dzerkalo tyzhnia. 6-12 zhovt. (No 39). s. 6. (in Ukrainian)

Bekh, I. (2006). Vykhovannia osobystosti. Skhodzhennia do dukhovnosti [Education of a Person. Ascension to Spiirituallity]. Kyiv : Lybid. 273 s. (in Ukrainian)

Buyeva. I. (2006). V. A. Sukhomlinskiy: gumanisticheskaya paradigma pedagogicheskogo menedzhmenta : monografiya [V.A.Sukhomlinsky: Humanistic Peradigm of Pedagogical Management : monograph]. N. Novgorod : VGIPU ; Orenburg : GOU OGU. 124 s. (in Russian)

Kokeryl, A. (2013). Sukhomlynskyi i XXI stolittia. [Sukhomlynskyi and XXI Century]. Pedahohika i psykholohiia. No 4. s.5-15. (in Ukrainian)

Sukhoiarska I. (2008). Humanizm yak osnova pedahohichnoi systemy Sukhomlynskoho 
[Humanism as a Basic in Sukhomlynskyi's Pedagogical System]. Pochatkova osvita. No 2324. s. 6-7. (in Ukrainian)

Sukhomlynskyi, V. (1977 a). Pavlyska serednia shkola. [Pavlysh Secondary School]. Vybrani tvory v 5 tomakh. T. 4. Kyiv: Radianska shkola. s.7-302. (in Ukrainian)

Sukhomlynskyi, V. (1976). Sto porad uchytelevi [One Hundred Tips for the Teacher]. Vybrani tvory v 5 tomakh. Tom 2. Kyiv: Radianska shkola, 1976. s.419-657. (in Ukrainian)

Sukhomlynskyi, V. (1977 б). Rozmova z molodym dyrektorom [Talking to a Young School Principal]. Vybrani tvory v 5 tomakh. T. 4. Kyiv: Radianska shkola. s.303-629. (in Ukrainian)

\title{
METHODOLOGICAL ASPECTS OF SUKHOMLYNSKYI'S CONCEPT OF HUMANISTIC EDUCATION
}

\author{
Natalia Pobirchenko \\ Doctor of Sciences (in Pedagogy), Professor, \\ Professor Extraordinary at the Faculty \\ of Social Sciences and Humanities \\ Viton State Higher Educational Institution in Lehnitsa, \\ Lehnits, Poland \\ ORCID:0000-0003-2125-7713 \\ e-mail:pobirchenko_n@mail.ru
}

\begin{abstract}
The article deals with the key methodological aspects of. V. Sukhomlynskyi concept of humanistic education. It was found that the main purpose of the concept of humanistic education of the prominent Ukrainian teacher is a child, the formation of her inner word, the inculcation of high spiritual needs, ensuring child's comprehensive development. The principle of humanism is the main one in the author's conception of education. The system of view of the great humanist educator on bringing up a child, which can be used by modern teachers in their practical activity, was examined.

The key aspects of the V. Sukhomlynskyi's concept are highlighted: education and upbringing; labor as a power factor in education; school and family; teacher and students; the school principal. The following key aspects of the concept of Pavlysh school principal are outlined: the vision of a child as the most precious treasure in the world that needs love, respect, faith, kindness, warmth and reasonable exactingness (the principle of childcentrism); the unity of family and school in the educational process; teacher's ability to communicate with students, find spiritual touch points in relationships with children, to make a positive impact on them; the importance of the role of the school principal in order to create high spirituality, family warmth and creative atmosphere in the collective, etc.

Predictions and perspectives of the V. Sukhomlynskyi's concept of humanistic education have been carried.

It has been proved that the concept of humanistic education, developed by V. Sukhomlynskyi, can be considered as a textbook on the methodology of education and training of students, which should become a handbook as well as for a novice teacher and a teacher with great experience of work.
\end{abstract}

Keywords: V. Sukhomlynskyi, humanistic education, concept of humanistic education, methodical aspects.

Стаття надійшла до редакиії 06.08.2019 p. 